\title{
O olho e a mão, o desenho na primeira viagem de Le Corbusier
}

\section{Joubert José Lancha}

Arquiteto, professor doutor do Departamento de Arquitetura e Urbanismo da EESC-USP, Av. Trabalhador Sancarlense, 400, Centro, CEP 13566-590, São Carlos, SP, (16) 3373-9800, lanchajl@sc.usp.br

\begin{abstract}
Resumo
O desenho, desde o renascimento sempre foi um dos principais problemas para os arquitetos, tão fundamental como o estudo do passado. Essas duas questões estiveram sempre caminhando juntas, uma promovendo e estimulando a outra. A obra de arquitetura possui uma determinada consistência e um absoluto encerramento: os desenhos servem para decompor essa consistência e romper seu hermetismo. Os inúmeros desenhos realizados por Jeanneret em suas viagens de estudos são testemunhos dessa intrínseca e estimulante relação: os edifícios e seus desenhos decompostos revelam-se como estímulo projetivo.
\end{abstract}

Palavras-chave: arquitetura moderna; desenho e representação de arquitetura

\section{ntrodução}

O papel das viagens de estudo para a formação cultural de Le Corbusier já é bastante conhecido. Mas ao mesmo tempo, o grande número de desenhos, repletos de detalhes e sugestões que o jovem Jeanneret produziu durante esse período, é um valioso legado que pode nos levar a refletir de forma mais alargada, sobre a arquitetura e um mundo de formas, sobre a cidade e seu desenho; que nos pertence como herança; colocando-nos diante de questões importantíssimas que dizem respeito à educação e a formação de arquiteto. Em suas viagens de estudo, diante de paisagens, cidades, edifícios e pessoas, acostumou-se a fazer vários desenhos e encher cadernos e cadernos de notas, com croquis e comentários de toda ordem. Transformando esse seu confronto direto com a obra em prerrogativa de trabalho que supera o momento de formação para permanecer como estratégia ao longo de sua atuação profissional. Seus inúmeros desenhos de observação se transformam ao longo de suas viagens, tanto quanto o seu olhar.
Re-visitando hoje esse percurso e lendo alguns dos desenhos e textos de sua primeira viagem de 1907, procuramos nas obras que, mais fortemente tocam Jeanneret a determinação do momento de constituição de uma particular alternativa de abordagem, análise e idéia da arquitetura. Suas anotações, croquis e desenhos surgem assim, como lampejos, iluminando aspectos ainda obscuros ou promovendo novos e possíveis vínculos.

Surpreende-nos colocar lado a lado os desenhos realizados por Jeanneret quando visita por duas vezes o Campo dei Miracoli em Pisa; na viagem à Itália de 1907 e em 1911 retornando de sua viagem ao Oriente. Comparar esses desenhos é esclarecer visivelmente um processo de maturação e desenvolvimento perceptivo realizado ao longo desses quatro anos. A diferença como os mesmos edifícios: Catedral, Torre e Batistério, em dois diferentes momentos são vistos e representados, revela uma extraordinária mudança em sua representação. Nos desenhos de 1907, (figuras 01 e 02) 
Figura 1: Vista e detalhe do Batistério. Pisa 6-10 de setembro 1907. (Fonte: CORBUSIER, Le. Le Corbusier, ॥ viaggio in Toscana, 1907. Catálogo da mostra org. por Giuliano Gresleri, Venezia: Marsilio, 1987)

Figura 2: Desenhos de particulares do Duomo. Pisa 610 de setembro 1907. (Fonte: idem, ibidem)
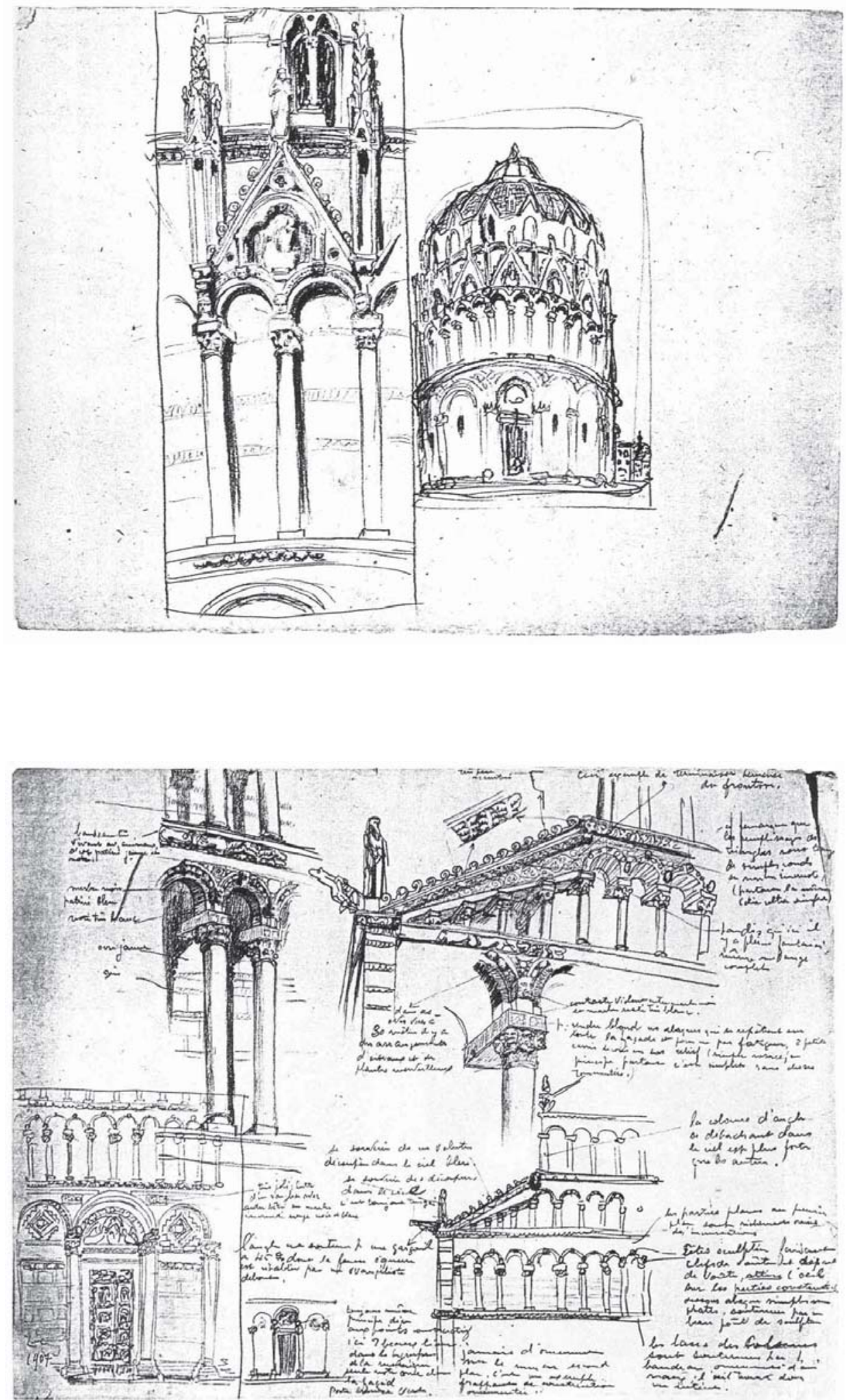
1 Jeanneret em 1907 escreve: "Com efeito, oque desenhar do Palazzo vecchio? Não se sabe de qual parte retirarIhe o seu mistério. "JEANNERET, Ch. E. Carta a L'Eplattenier. Firenze, 19 de setembro 1907.

2JEANNERET, Ch. E. Carta a L'Eplattenier, Firenze, 19 de setembro 1907

Figura 3: Duomo, Batistério e mura da cartuxa.Pisa, outubro 1911. (Fonte: Catálogo da mostra Viaggio in Oriente. Venezia, Marsilio/ Fondation Le Corbusier, 1984)

Figura 4: Abside do Duomo e torre. Pisa, outubro 1911. (Fonte: idem, ibidem) um sobre o Batistério e o outro sobre a Catedral podemos ver um Jeanneret preocupado em registrar as fachadas de cada um desses edifícios e seus detalhes de ornamentação. Na folha do Batistério, reproduz a fachada através das colunas, frisos e ornamentos, com dois desenhos: um menor de todo o edifício e um outro parcial, um recorte ampliado da fachada, que evidencia essa seqüência de elementos. A prancha sobre a Catedral é construída através de uma seqüência de aproximações; cada um dos cinco desenhos apresenta novos detalhes, enchendo a página com o maior número de fragmentos possível, cuidadosamente observados e completados com o auxílio de muitas notas escritas ao largo dos desenhos, acreditando que a partir do rigoroso resgate dessa infinidade de partes estaria conseguindo retirar a essência da obra ou o seu "mistério". 1 Essas várias anotações textuais que comparecem margeando os desenhos, descrevendo elementos arquitetônicos e decorativos, suas cores, contrastes e sua opinião em breves frases serão retomadas e posteriormente descritas em uma de suas cartas a L'Eplattenier:

"A Catedral às seis da tarde é uma magia de cores, é a quintessência de todas as tonalidades de amarelo, ressalto de branco marfim e das pátinas pretas, tudo sobre um [céu] ultramar de um valor extraordinário; no ímpeto de olhá-lo novamente o vemos preto. A parte sobre a qual o batistério projeta a sua sombra é uma tranqüila vibração de amarelos intensos, de mármores pretos que se tingem em azul, é a vitória das superfícies planas que vibram e falam docemente." 2

Já em 1911, voltando de sua viagem ao Oriente visita mais uma vez Florença e Pisa e realiza outros desenhos (figuras 03 e 04) sobre o Campo dei
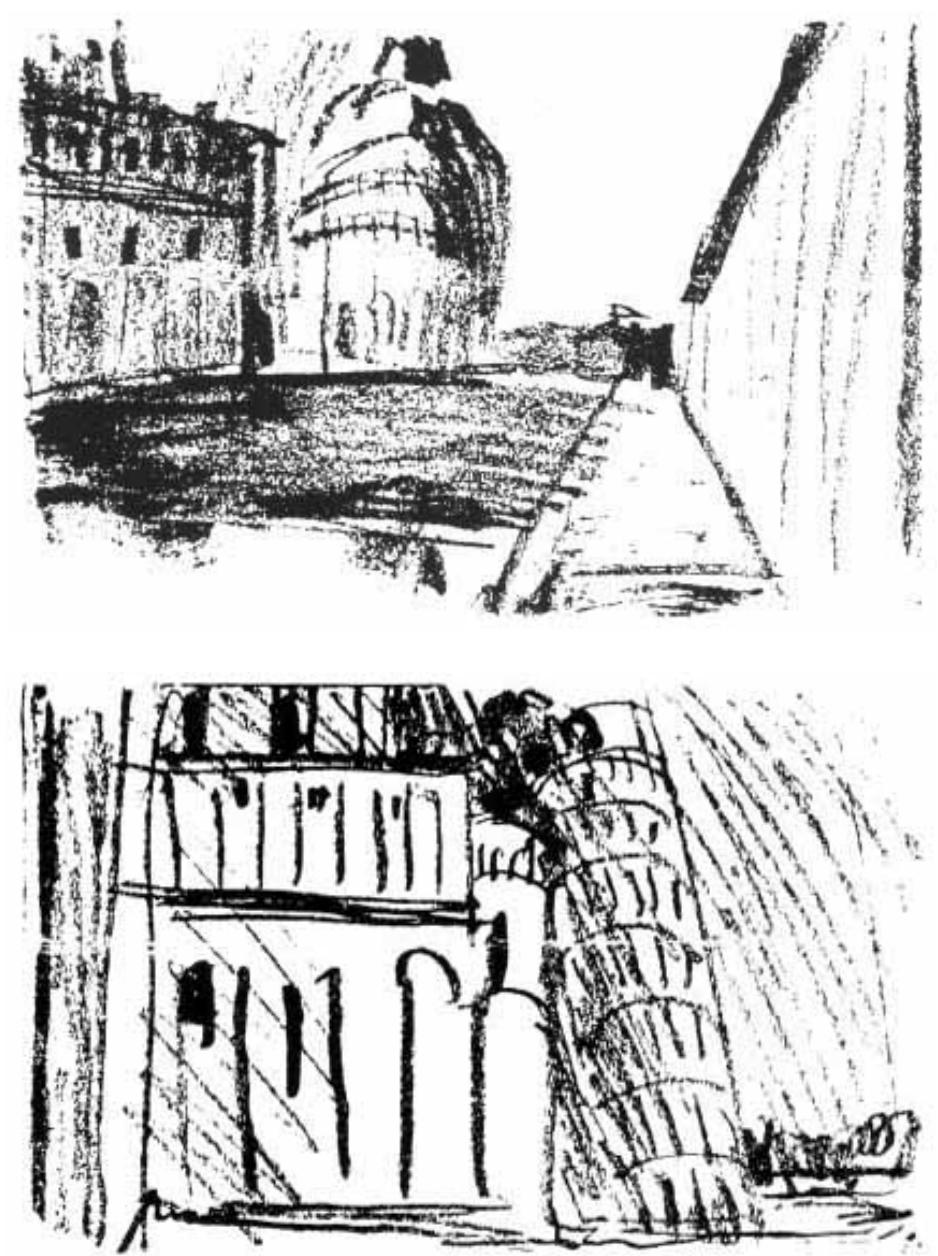
${ }^{3}$ GRESLERI, G. Le Corbusier, viaggio in Oriente. Veneza: Marsilio, 1984, pp.18.

${ }^{4}$ Paul Bouvier (1857-1940) foi o primeiro mestre de L'Eplattenier, arquiteto de Neuchâtel saído da escola de Beaux Arts de Paris.

${ }^{5}$ GRESLERI, G. Viaggio e scoperta, descrizione e trascrizione. In: Revista Casabella n. 531-532. Milano: Electa, 1987. pp: 8-17. Gresleri aponta um outro livro, presente de L'Eplattenier enviado pelo correio à Firenze, Les Grands Initiés de Schuré. Uma obra destinada a completar uma educação que vem da Grammaire de Jones e sobre o Méthode de Grasset, autores para os quais os lugares desta e das outras viagens de Jeanneret não tinham segredos. JEANNERET, Ch. E. carta a L'Eplattenier. Firenze 8 de outubro 1907.

${ }^{6}$ GRESLERI, G. (1984) op.cit. p.08. Estando mais atento as obras que estavam em sintonia com o pensamento de L'Eplatenier destacando: o gótico local, a pintura primitiva, os ambientes organizados da vida coletiva e os lugares da representação funeraria.

${ }^{7}$ A correspondência de Jeanneret desse período foi publicada em: GRESLERI, G. Le Corbusier.Viaggio in Toscana (1907).Veneza: Marsilio, 1987.pp.119-140 e em GRESLERI, G. (1984), op.cit.,pp.: 357-405.

${ }^{8}$ Assim, essa primeira viagem de aproximadamente dois meses (setembro a novembro de 1907), se realiza segundo o seguinte itinerário de visitas: De La Chaux de Fonds (1 de setembro) para Bern, Luzem, Gottardo, Lugano chegando a Milão (4/5 de setembro). De Milão a Pavia, Genova, Carrara, Pisa e Firenze onde faz sua estadia mais prolongada, permanecendo por cerca de um mês visitando as cidades próximas. Depois de Firenze segue em direção a Veneza passando por: Faenza, Ravena, Ferrara, Bolonha, Mantova, Peschiera, Gargnanao, Riva, Desenzano, Verona, Padova e parmanecendo em Veneza (25 de outubro a 7 de novembro).

9 JEANNERET, Ch. E. Carta a seus pais, 5 de setembro de 1907.
Miracoli. Mais rápidos, mais soltos e sintéticos que aqueles de 1907, são dois desenhos intensos, tira partido da pressão do lápis sobre o papel revelando através das sombras, a força do edifício. Enfoca a relação entre os edifícios e não mais o edifício isolado e seus detalhes singulares, compreende dessa vez o Campo dei Miracoli como um conjunto, e seu desenho deixa de ser uma coleção de fragmentos. Seu desenho agora revela o edifício e sua massa construída na intensidade de contrastes, luz e sombra. A conquista em definitivo dessa alternativa de desenho, embrionária em sua viagem à Itália, só é possível depois de sua viagem ao Oriente.

\section{A Viagem a Itália de 1907}

Quando Jeannert, em 1907 organiza sua viagem de estudos, a "viagem à Itália" já fazia parte da tradição pedagógica também na escola de Artes de La-Chaux-de-Fonds. Alguns outros alunos, como é o caso de Léon Perrin, já haviam realizado suas viagens particulares de estudo à Itália. O próprio L'Éplattenier, seu mestree na escola, em 1903 e 1904 realizou duas viagens de estudos e incentivava seus alunos para que fizessem o mesmo.

Jeanneret, juntamente com seu mestre elaboram um roteiro muito bem definido, semelhante àquele que realizara L'Eplattenier três anos antes, através das cidades da região da Toscana. L'Eplattenier pôde cuidadosamente construir um "carnet de voyage", um pequeno caderno de desenho onde anotava grande parte de suas impressões e descobertas. Caderno que nesse momento serviria como "referência obrigatória" para Jeanneret e segundo Giuliano Gresleri ${ }^{3}$ as viagens de Bouvier ${ }^{4}$ é que na verdade guiam L'Eplattenier. Outras referências ${ }^{5}$ para Jeanneret compreender um pouco mais a respeito das cidades e das obras e seus autores são: Baedeker, Voyage di Taine e Les Matins a Florence de Ruskin J. e ainda o Dictionnaire de Viollet-le-Duc; os quais Jeanneret coloca em confronto com suas próprias impressões. Além disso, teve contato com um periódico mensal, "Mon Voyage d'Italie" da Comptoir revista, muita bem ilustrada que sua mãe assinava, que lhe deu uma visão mais abrangente das "belezas" da Itália em geral, e de Florença em particular. ${ }^{6}$
O itinerário dessa que seria a sua primeira viagem, realizada em companha de seu amigo escultor Lon Perrin de setembro a novembro do ano de 1907 foi reconstruído por Giuliano Gresleri ${ }^{7}$, através da sistematização e da análise da correspondência mantida por Jeanneret com seus pais e com L'Eplattenier durante todo o período de permanência na Itália ${ }^{8}$. Algumas cartas são bastante longas, revelam as empatias e dissabores diante das cidades e das obras visitadas. Quando escreve para seus pais as reclamações são constantes e mostram algumas das dificuldades cotidianas de Jeanneret. Já as cartas para L'Eplattenier são descritivas, procura sistematizar para o mestre as observações que nas visitas são anotadas nos desenhos, pede conselhos e revela suas escolhas e afinidades diante das obras. São aproximadamente vinte e cinco cartas e mais de setenta desenhos e aquarelas dedicados à região da Toscana.

A primeira cidade visitada é Milão, onde realiza uma tradicional excursão, percorrendo a Catedral, o cemitério monumental e o Campo Santo, deixando de lado obras muito mais relevantes para a cidade como o Castelo Sforzesco, Santo Ambrogio e Brera, além das recentes obras realizadas por Portaluppi, Beltrami e Broggi. Sua empatia com a Catedral é assim descrita: "A Catedral é magnífica externamente, imponente e comovente internamente, sobretudo é enorme." 9 Escrevendo a L'Eplattenier é ainda mais contundente: "Em Milão chego às duas na praça da Catedral; havia tanto barulho que me refugiei no interior, lá que grandeza (mistério da floresta), é fabuloso, é maluco. Pouco a pouco vai se habituando, depois se percebe improvisamente um pequeno homem ao lado de uma coluna, o olho começa a medir e termina estonteado" ${ }^{10}$. A Catedral de Milão é assim, a primeira de suas grandes emoções arquitetônicas, uma vez que a experiência arquitetônica de Jeanneret era muito pequena, conhecia os modestos edifícios da região montanhosa de Neuchâtel. Saindo de Milão em direção a Genova faz uma parada na Cartuxa de Pavia, edifício de 1392. Essa visita Ihe trará grande satisfação e entusiasmo, em função de um dos aspectos mais fascinantes dos monastérios e em particular das cartuxas, a estreita harmonia que liga indivíduo e comunidade. Harmonia que irá reencontrar na Cartuxa de Ema, quando de sua 


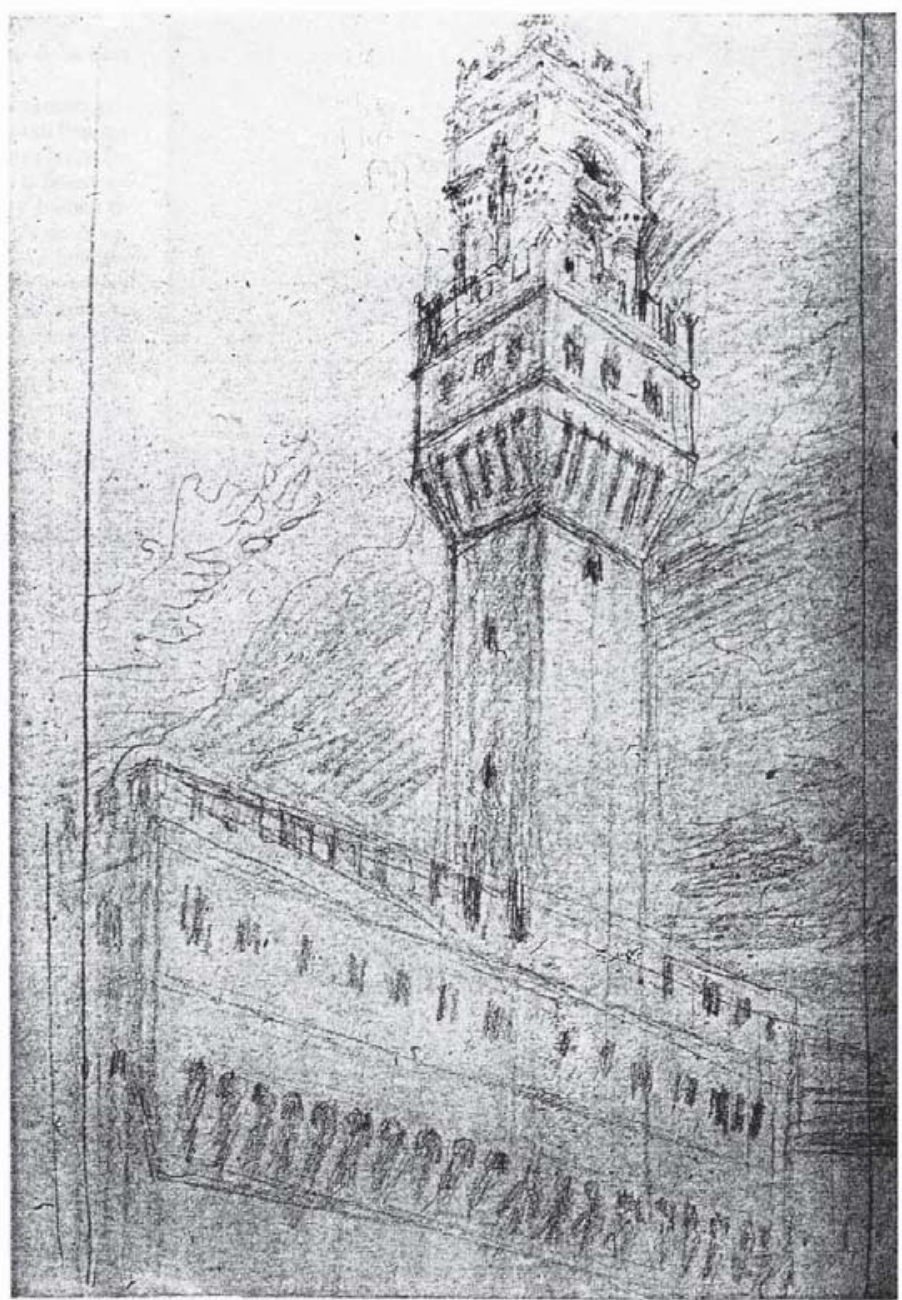

Figura 05: Palácio Vecchio. Florença, depois de 10 de setembro 1907. Fonte: CORBUSIER, Le Le Corbusier, ॥ viaggio in Toscana (1907). Venezia: Marsilio, 1987.

10 JEANNERET, Ch. E. Carta a L'Eplattenier, Firenze, 19 de setembro 1907.

${ }^{11}$ JEANNERET, Ch. E. Carta a L'Eplattenier, Firenze, 19 de setembro 1907.

${ }^{12} \mathrm{Em}$ 1907, ano de início da viagem de Jeanneret pela Itália, o guia Baedeker havia chegado a sua décima sexta edição. L'Italie Septentrionale tem sua primeira edição em 1873, e a fama do novo manual para o viajante que se estadia em Florença. Chega a Pisa onde permanece por cinco dias, visita a piazza dei Miracoli e fica totalmente impressionado com a Catedral descrevendo-a dessa maneira: "Fiquei quatro dias nessa praça; só sai por algumas horas no domingo e segunda feira para ir ao museu cívico.... A fachada da Catedral é simplesmente maravilhosa e não encontrei ainda nada similar." 11

Algumas das opções de visita que Jeanneret estará fazendo, foram ditadas por L'Eplattenier, outras tantas são derivadas da literatura e dos guias de viagem da época. ${ }^{12}$ Mas sem dúvida, o paradigma primeiro é a obra de John Ruskin, e suas viagens à Itália de 1840/41 e 1845. ${ }^{13}$ Para Ruskin, existe uma supremacia da arquitetura diante das outras artes e o ornamento é seu elemento principal, o modelo ideal é a cidade medieval, produzida coletivamente e construída a partir de expressões diversas, por sua vez o Renascimento corta essas relações, colocando-se acima da estrutura social. A crítica de Ruskin ao Renascimento define, em grande medida, a rígida seleção que Jeanneret estará fazendo em seu itinerário italiano, muitas vezes deixando de lado importantes obras desse período, ${ }^{14}$ exceção feita às obras de Michelangelo e Raffaello.

"Se critica a fundo obras tidas como belas por gerações, e é perfeitamente compreensível porque são cinco séculos de erro e engano; e eu não poderia malgrado os sinceros elogios do senhor Baedeker, andar em êxtase diante dessas coisas horríveis. " 15 (figura 05) 
"aventura" pela Itália foi tão rápida que promoveu contínuas revisões e aperfeiçoamentos, fazendo também surgir outros celebres guias como os de Murray e de Foster. Gresleri afirma ainda que o Baedeker, pela sua tendência a explicar, historiar e compreender o contexto se transforma no primeiro guia "moderno". GRESLERI. G. (1987) op.cit.

${ }^{13}$ Ruskin, aos vinte e um anos de idade, parte para a sua primeira viagem que duraria dois meses e seguia o itinerário clássico do Gand Tour. também ele carregando seu próprio álbum de desenhos. Ruskin tem uma formação de alto nível que compreende estudo de desenho e aqua-

Figura 06: Desenho Ruskin - Palácio Ducal visto da lagoa 1845. Fonte: Ruskin, John. Viaggi in Italia. Org. por Brilli, Attilio. Passigli Editori, Florença, 1985.
Mas a influência de Ruskin não deve ser atribuída só ao itinerário e à seleção das obras. Jeanneret observou também seus desenhos e a aproximação entre eles é muito evidente. A escolha do enquadramento do edifício na página, o enfoque figurativo dado à sua representação servem de estímulo inicial também à produção de Jeanneret. Ruskin se preocupa com as fachadas, com a paisagem, elemento prioritário de sua investigação, reveladas através de detalhes onde o contraste mais intenso entre figura e fundo é sempre explorado. As fachadas dos edifícios são observadas como elementos pictóricos, reveladas por suas cores, texturas e contrastes e muito constantemente elas são representadas parcialmente como, por exemplo, no desenho do Palácio Ducal em Veneza onde é detalhada a lateral direita do edifício e o restante da fachada vai se esfumaçando até sumir. Como veremos mais adiante em grande parte de seus desenhos de arquitetura também Jeanneret procura resgatar e detalhar parciais da fachada em detrimento da completude do edifício. (figura 06)

De Pisa parte para Florença para cumprir um dos primeiros objetivos dessa sua viagem, que é a visi- ta às cidades da região da Toscana. Passa então um grande período, o maior dessa sua viagem de dois meses, de 11 de setembro a 10 de outubro, hospedado em Florença visitando as cidades de Prato, Filesole, Galluzzo, Siena, Lucca e Pistoia. Durante esse longo período em Florença, construindo com isso uma relação mais próxima com a realidade da cidade e da própria Itália, como até então não houvera oportunidade, determinado e absorvido pelo olhar focalizado estritamente sobre as obras de arte. Na correspondência de Jeanneret com seus pais, fica nítido seu desconforto com o cotidiano e a realidade das cidades italianas, mostrando-se muitas vezes bastante imaturo ao queixar-se da comida e dos albergues. Mas, suas críticas perdem esse caráter inconformado e percebe-se que Jeanneret, hospedado em Florença começa a se envolver com as peculiaridades italianas. ${ }^{16}$

Em Florença se instala em um albergue na esquina entre as ruas Calzaioli e piazza della Signoria, onde da janela de seu quarto tem uma visão esplendida sobre a praça e pode comodamente, a partir dessa perspectiva realizar alguns desenhos do Palazzo

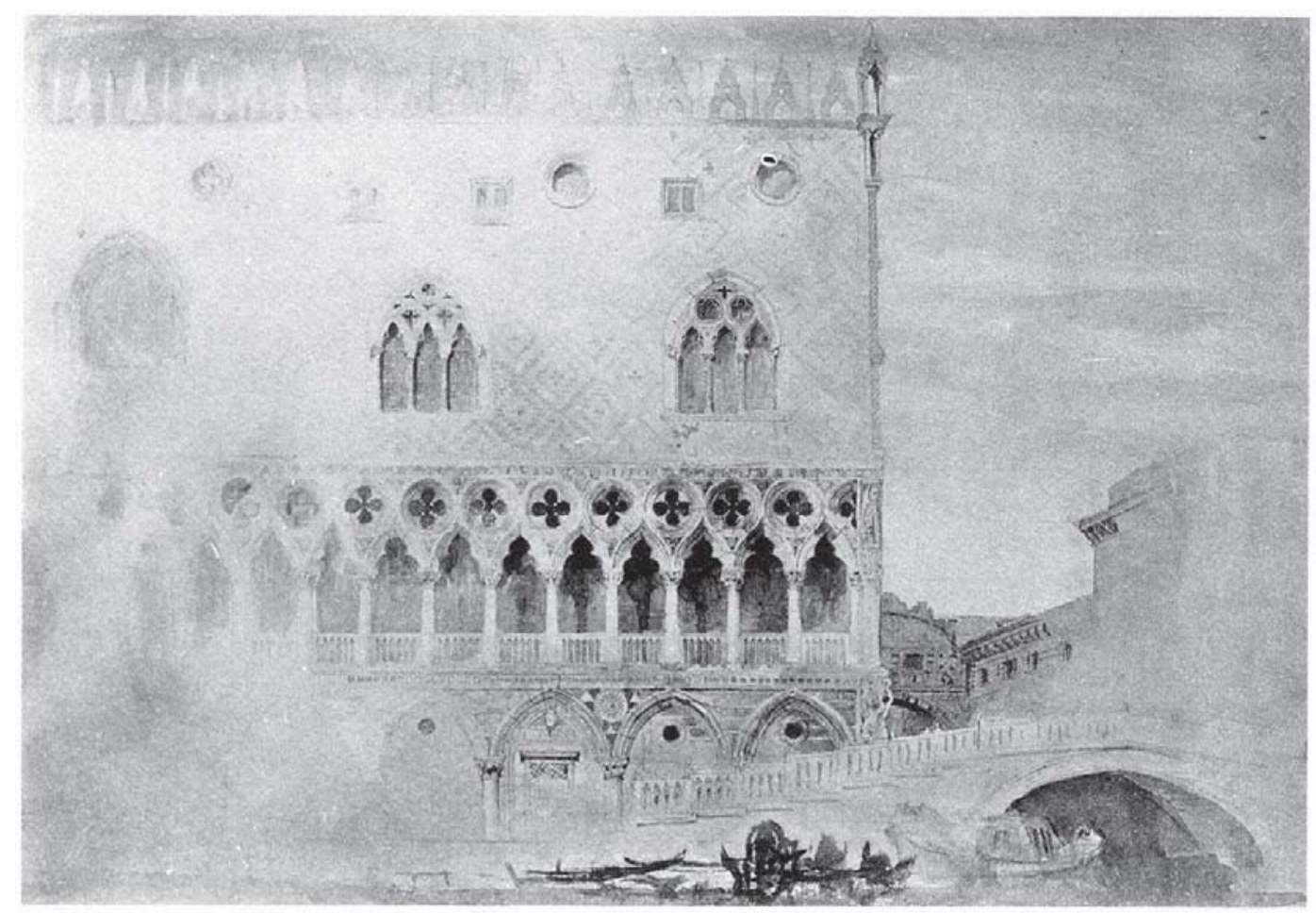


rela, estudo e prática sobre a tradição continental e britânica da pintura de paisagem. Sobre as viagens de John Ruskin, além dos livros: Mattinate Fiorentine e Le Pietre di Venezia verificar: Viaggi in Italia 1840-1845. Firenze: Passigli Editore, 1985.

${ }^{14}$ GRESLERI, G (1987). p.43. Gresleri traça um paralelo entre as cartas escritas por Jeanneret em Florença e as "Mattinate Fiorentine" de Ruskin, revelando esses vínculos de escolha de obras.

${ }^{15}$ JEANNERET, Ch. E. Carta a seus pais; Padova 24, outubro 1907.

${ }^{16}$ JEANNERET, Ch. E. Carta a seus pais; Firenze 14, setembro 1907. Jeanneret escreve: "A raça italiana me parece muito decadente, muito degradada: não Ihe resta mais nada. Já escrevi a vocês, este é o pais da sujeira, pior, é o reino da sujeira. Administração, albergues, negócios, pensões, é sempre a mesma história. Mais adiante, no dia 15, ainda nessa mesma carta escreve: A cozinha caseira é assim pesada que pela manhã, não se tem nenhuma vontade de comer". Juízo que pouco a pouco se transforma, como no comentário que faz ao final da pequena carta a seu pai em 22 de outubro 1907, depois de ter saído de Florença: Viva a Itália e pensar que já é o final do belo sonho! Ou ainda em 24 outubro: "Para concluir, estes italianos são mais cômicos que desagradáveis, e aqui eu me divirto."

${ }^{17}$ Todos realizados posteriormente à data de: 10 setembro de 1907. Não se tem a data precisa.

${ }^{18}$ JEANNERET, Ch. E. Carta a L'Eplattenier; Firenze 19, setembro 1907.

${ }^{19}$ JEANNERET, Ch. E. Carta a seus pais; Firenze 14, setembro 1907.
Vecchio. Desenhos oportunos para serem destacados por aquilo que neles é possível observar e inferir como princípios norteadores de suas observações e estudos. São três folhas, não datadas (figuras 03/04/05), ${ }^{17}$ com desenhos de observação do palácio; a primeira traz um desenho que é quase um esquema do edifício composto em toda a extensão da página e apresenta as principais relações volumétricas do edifício, realizado a lápis sobre papel, que serviria provavelmente como base para uma futura aplicação de aquarela. O segundo desenho, e talvez o mais elaborado em função do maior número de detalhes, se compõe de três vistas parciais do palácio. Uma vista principal que domina a página e mostra parte do edifício em ângulo, essa vista recebe duas linhas de cota (horizontal e vertical), onde Jeannert procura anotar as proporções existentes na construção da fachada do palácio. À direita desse desenho no alto da folha uma outra vista do palácio e ao lado do desenho um longo texto repleto de comentários e descrições dos elementos que compõe a fachada. Na parte de baixo da folha, um outro trecho do palácio, um desenho da torre de Arnolfo. A terceira folha de desenho mostra um detalhe do coroamento da torre de Arnolfo que ocupa toda a página. Desenhada com muito apuro, revela cada elemento explorando suas relações de luz e sombra. Nesses três desenhos Jeanneret passa de uma apreensão global do edifício em sua forma à explicitação de seus particulares, movimento que estará realizando na observação de outras obras como Santa Croce, Santa Maria Novella, Orsanmichele e etc., construindo uma espécie de zoom em uma visão seqüencial.

"Florença é uma cidade completa, observo-a mais como turista que como especialista. Com efeito, o que desenhar do Palazzo Vecchio? Não se sabe de qual parte retirar o seu mistério. É desconcertante, existem acabamentos muito delicados sobre sua fachada brutal, tanta força em sua torre, uma cor assim quente, assim plena e dizer que o palácio Federal é de estilo fiorentino! Agora mais que nunca, eu não entendo nada." 18

Ainda em Florença no dia 15 setembro, Jeanneret vai conhecer a Cartuxa de Ema, em Galluzzo. Sua estrutura funcional, não difere substancialmente da Cartuxa visitada em Pavia, uma organização espacial bastante típica dos monastérios cartuxos, desenvolvidos a partir do claustro, preferivelmente quadrado, que com a arcada organiza as celas dos monges. A tipologia de uma Cartuxa é definida por uma série de funções e das suas recíprocas relações; o pátio de ingresso, claustro maior e claustro menor, áreas vazias que determinam a estrutura de organização formal e funcional do complexo.

Em suas correspondências, Jeanneret observa na Cartuxa de Ema dois elementos principais de atração; a inserção do edifício na paisagem e o conjunto do claustro e celas dos monges: "Estive ontem na cartuxa de Ema, espero não ter já Ihes contado e ali encontrei a solução para a casa operária tipo único. A única coisa que será difícil encontrar é esta paisagem. Que sortudos esses mônacos! Sábado pela manhã, a Fiesole, que sortudos esses monges!, a minha admiração foi a mesma na cartuxa de Pavia e pude convencer-me que, todavia renunciando ao mundo, eles sabem ao menos procurar para si uma vida deliciosa, e sou persuadido a crer que, ao fim das contas, eles é que são felizes e sobretudo são ainda eles que tem em vista o Paraiso." 19

A cela é autônoma em relação a cartuxa, seu acesso ocorre através da galeria do claustro e um pequeno corredor interno a isola ainda mais. Entrando na cela à esquerda uma escada com duas rampas leva para a cantina abaixo e ao piso superior (piso eventualmente existente e reservado ao quarto de dormir). À direita se acessa uma pequena varanda aberta para o jardim com um poço de água. No piso térreo existem ainda duas salas que se comunicam; a primeira dotada de lareira e mesa dobrável era o lugar aonde era consumido o alimento e se realizava a pregação, sala que era denominada "Ave Maria" e a sala ao lado servia de laboratório. Da primeira sala, um pequeno corredor dá acesso a um pequeno serviço higiênico. Cada cela dispunha de um pequeno jardim trabaIhado pelo monge, este o ajudava a superar as dificuldades do isolamento. A grande admiração que Jeanneret expressa pela "vida deliciosa" demonstra sua reflexão sobre as relações que ligam o homem à sua casa e à sua intimidade, como observa em seus desenhos, tanto em Ema como em Pavia, por suas reduzidas dimensões e pelas relações funcionais e distributivas desses espaços. Pensando no habitar moderno Jeanneret vê na 
Figura 7: Palácio Vecchio, vista da casa da rua dei Calzaioli. Florença, depois de 10 de setembro 1907. (Fonte: CORBUSIER, Le Le Corbusier, II viaggio in Toscana, 1907. Venezia: Marsilio, 1987)

Figura 8: Detalhe da Torre de Arnolfo. Florença, depois de 10 de setembro 1907 . (Fonte: idem, ibidem)
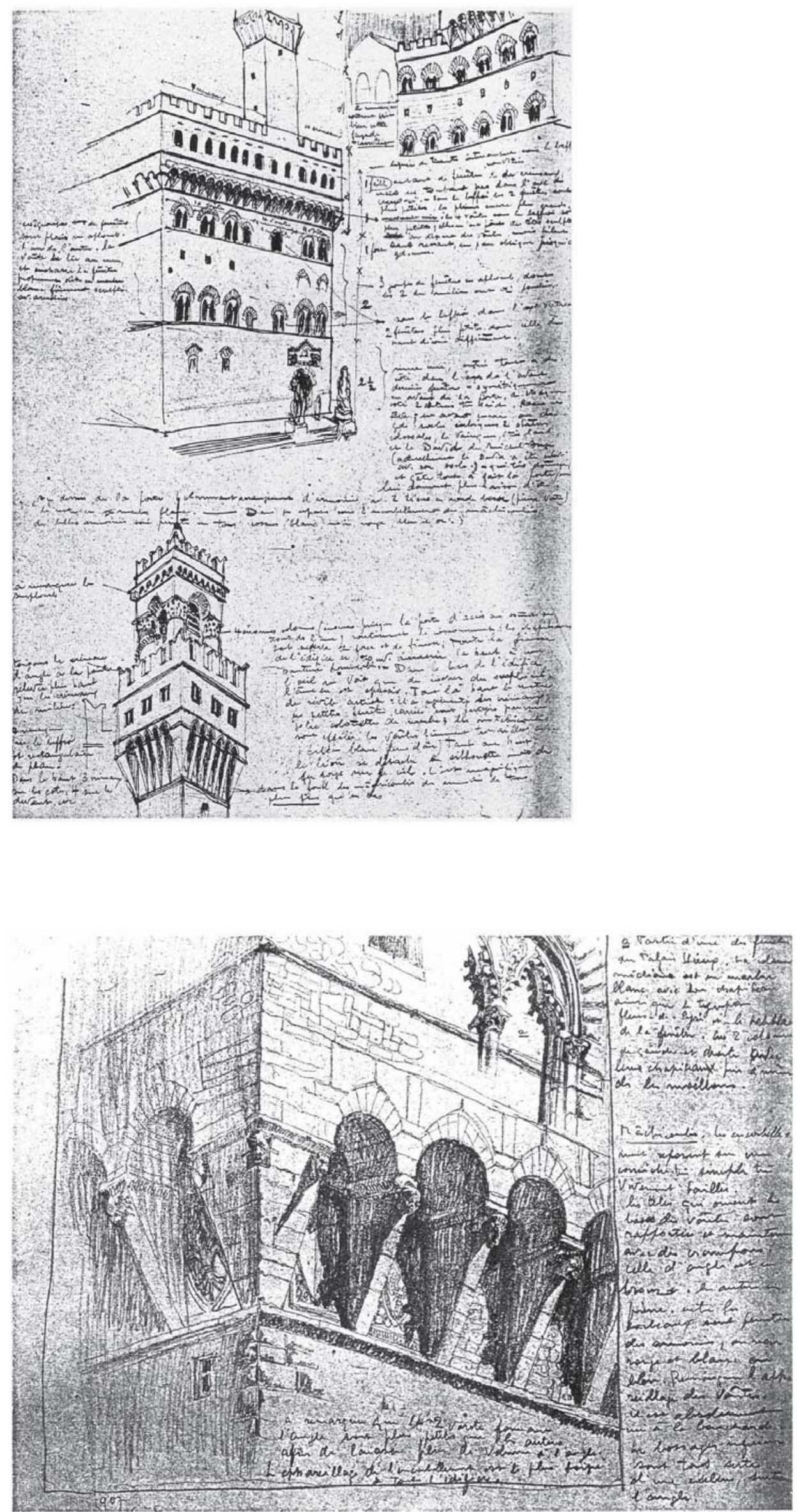


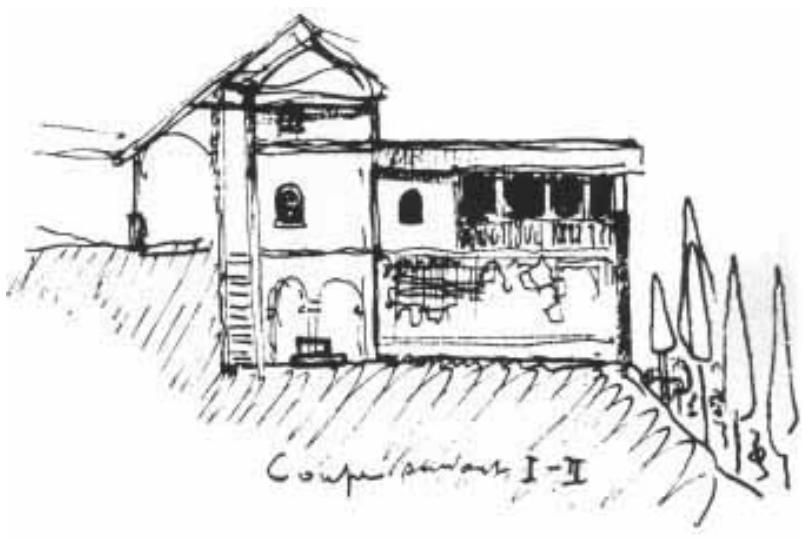

Figura 09: Cartuxa de Ema em Galluzzo, corte com anotações. Florença: outubro 1911. (Fonte: CORBUSIER, Le. Le Corbusier, II viaggio in Toscana, 1907. Venezia: Marsilio, 1987)

Figura 10: Cartuxa de Ema em Galluzzo, planta de uma cela com diversas anotações. Florença: outubro 1911. (Fonte: idem, ibidem)

Figura 11: Cartuxa de Ema em Galluzzo, vistas do pátio de uma cela. Florença: outubro 1911. (Fonte: idem, ibidem)

${ }^{20}$ Esses dois desenhos de Jeanneret foram realizados em 1911, momento em que Jeanneret retornava de sua viagem ao Oriente e passa novamente por Firenze. Esse desenho, com anotação das cotas, é realizado com traços rápidos, característica de um Jeanneret pós Istambul. Esses desenhos foram ainda publicados no livro de PETIT, J. Le Corbusier, lui meme. Genève 1975, p. 43.

${ }^{21}$ JEANNERET, Ch. E. Firenze, 15 setembro 1907.
Cartuxa uma alternativa, onde é possível um equilíbrio entre o viver coletivo e individual.

Da cela da Cartuxa de Ema realiza dois desenhos, ${ }^{20}$ planta e seção, com anotações de detalhes. Na lateral descreve em itens alguns elementos e ao pé da página escreve: "Cela de um frade na Cartuxa de Ema. Poderia perfeitamente aplicar essas soluções às casas / operarias, o bloco da célula é inteiramente independente. Tranqüilidade, surpreendente; o grande muro poderia esconder a vista da estrada".

Essa sua "descoberta" estará sempre a repercutir em seu trabalho. ${ }^{21}$ Jeanneret desenvolve essa capacidade, de observar, de compreender os elementos e com eles intuir novas possibilidades de organização. Fará uso da organização da cela cartuxa e do claustro redesenhado na tentativa de buscar um modelo tipológico que usará como referência no projeto para os "Ateliers de Artistas" de 1910 que se constitui por um bloco central comum que recebe em seu entorno pequenas celas laboratório. Mas é no projeto para as "Immeuble Villas" de 1922, e posteriormente no Pavilhão de "L'EspritNoveau" de 1925 que essa relação de correspon-

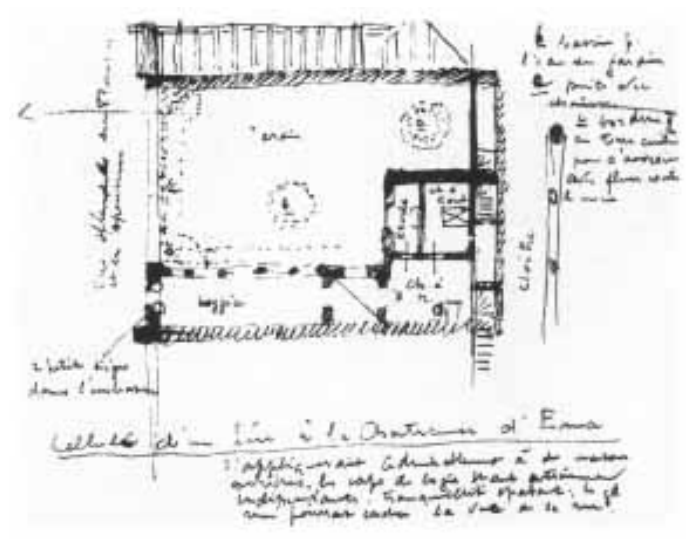

dência se fará de forma ainda mais extraordinária. O edifício é organizado em torno a um pátio central para onde convergem todas as unidades. Esse pátio acolhe também os corredores de distribuição, que funcionam como as arcadas no claustro. A célula possui dois pisos e tem uma planta em "L" que é resultado da inserção de um terraço jardim de pé direito duplo, que restabelece a relação do jardim interno da cela dos monges. Os ambientes de banho e cozinha concentram-se na face interna do edifício permanecendo os espaços mais abertos para a sua face externa. Corbusier estará produzindo com a idéia desse edifício, "um dos protótipos mais extraordinários do habitar contemporâneo", e cinqüenta anos depois de sua primeira viajem a Itália, as influências dessas visitas às Cartuxas ainda estariam repercutindo em seu trabalho no projeto para a "unités d'habitations de grandeur conforme".

"Depois do almoço, estou na cartuxa de Ema. Oh os cartuxos! Gostaria de morar toda a minha vida naquelas que eles chamam de as suas celas. É a solução da casa, tipo único ou mais ainda do paraíso terrestre!" 22

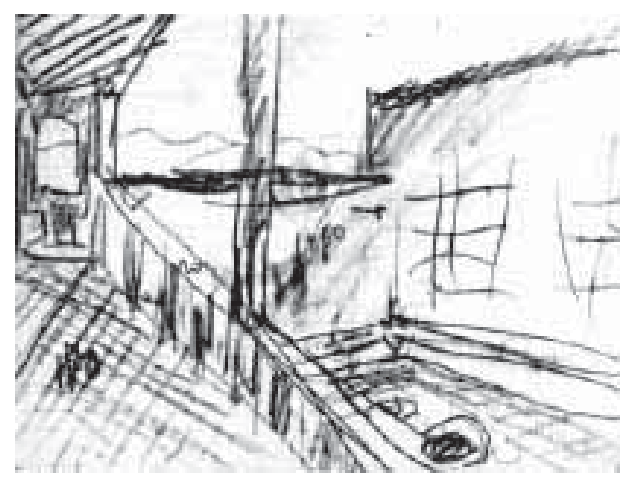


${ }^{22}$ JEANNERET, Ch. E. Carta a L'Eplattenier; Firenze 19, setembro 1907.

${ }^{23} \mathrm{GOBBI} ; \mathrm{G}$; SICA, P. Charles E. Jeanneret a firenze nel 1907: Assenze e presenze. In: Gresleri,G.(1987) op.cit. p.32. Nesse artigo Gobbi e Sica traçam um panorama da cidade de Firenze no período da viagem de Jeanneret e, seguindo seus passos revelam suas opções para a estadia em Florença.

${ }^{24}$ JEANNERET, Ch. E. Carta a seus pais; Siena, 1 de outubro 1907.

Figura 12: Pátio do Bargello, vista do pátio. Florença: outubro 1907. (Fonte: CORBUSIER, Le. Le Corbusier, II viaggio in Toscana, 1907. Venezia: Marsilio, 1987)
Ainda em Florença, depois da visita à cartuxa de Ema, vai a Bargello e a igreja del Carmine, ao museu arqueológico, a Academia para ver Botticelli e Angelico, visita o Battisterio e a porta do Paraiso, a Santa Croce, e a Fiesole, Orsanmichele e novamente o Museu arqueológico. Mas o itinerário de Jeanneret em Florença é construído de modo muito particular, são muitas e importantes obras que passam sem sua mínima menção, ${ }^{23}$ porém é o encantamento com a cidade e sua arquitetura que passa a fascinar Jeanneret:

"Cidade extraordinária, que fascinaria papai; pitoresca, não imagino o que poderia ter à mais, é inacreditável, a cada momento devemos parar, com o nariz para cima, diante de espetáculos desconcertantes.Tudo de uma só vez, ao alto no céu, você tem a enorme massa da catedral, na sua frente os muros de sustentação de casa que se lançam até 20 metros, compactas, vermelhas de uma tonalidade de tijolos muito fina. Aqui tudo em tijolo, a fantasmagoria dos tons vermelhos, vermelho vinho e malva. Única no mundo a praça do Palazzo comunale. Cidade muito prazerosa de morar, com muitas árvores, e por toda parte visões sobre a planície e sobre os Apeninos." 24

Visita Siena e pela primeira vez, descreve a cidade de maneira prazerosa elabora vários desenhos da piazza del Campo da Catedral e do Batistério, mas dentre todos esses existe um que se destaca. É o desenho que traz a piazza del Campo representada através de planta e elevação. Seu destaque se refere à novidade que apresenta: é o único desenho a ser

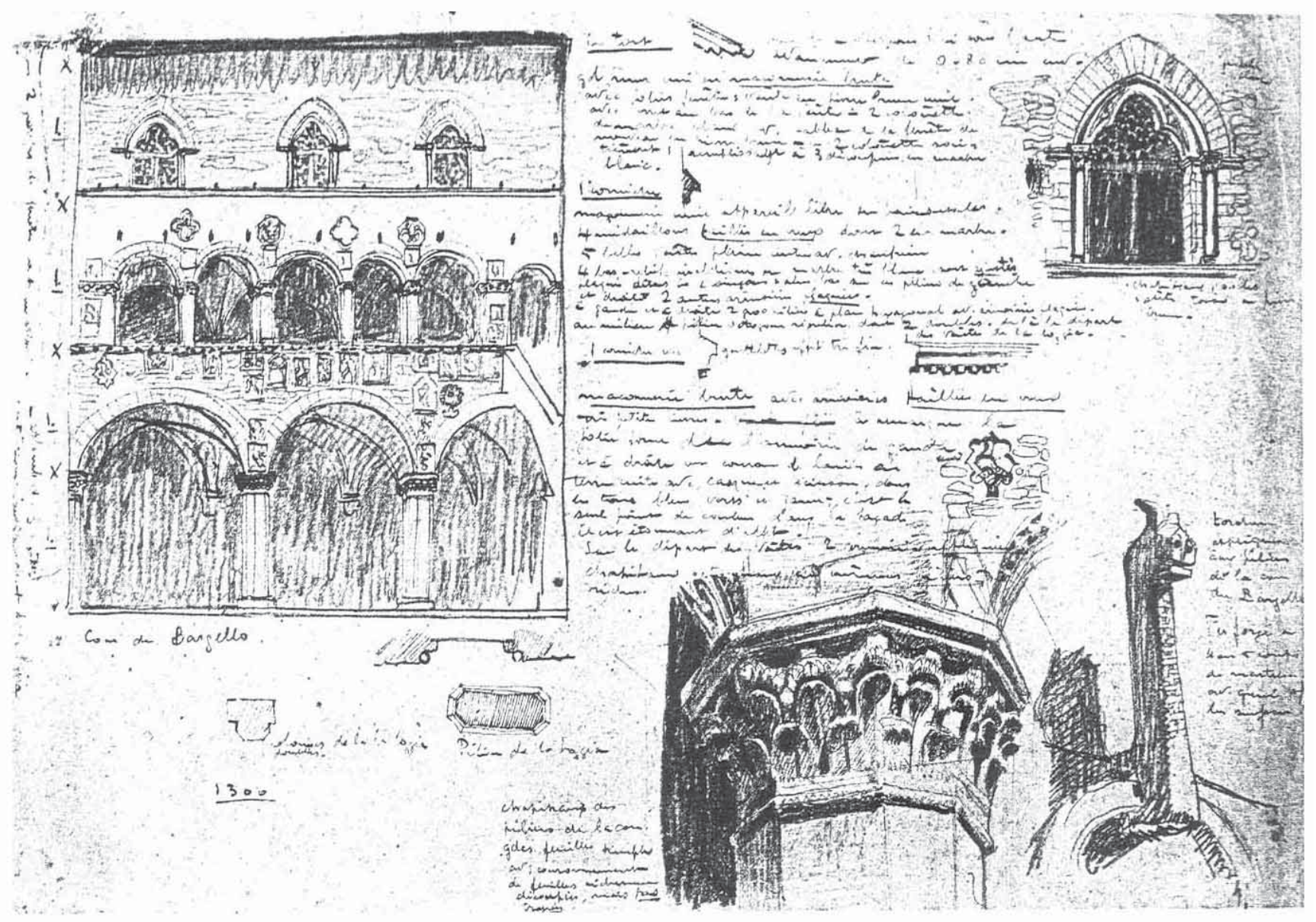




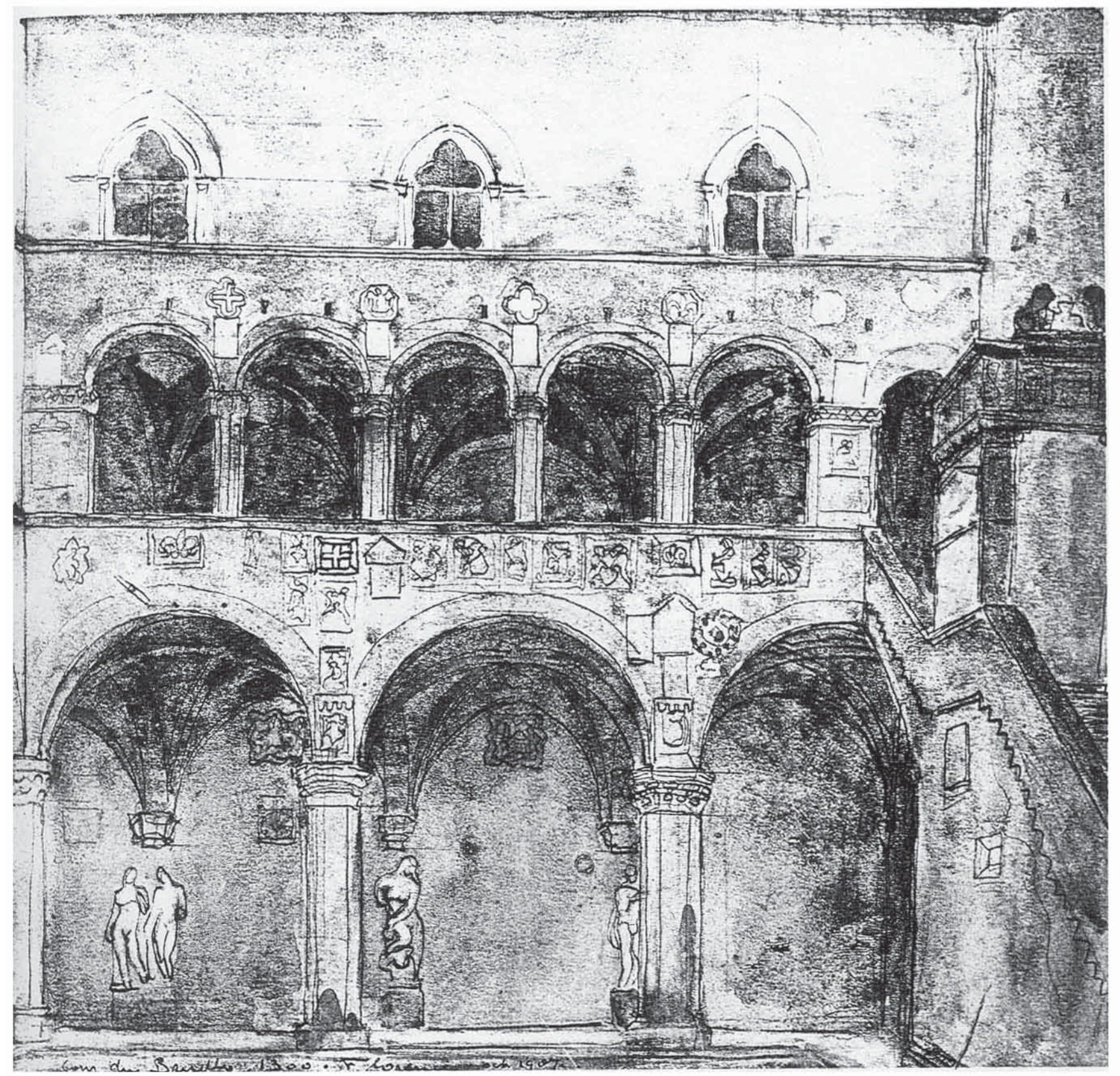

Figura 13: Estudos do pátio

do Bargello vista do pátio. Florença: outubro 1907. (Fonte: CORBUSIER, Le. Le Corbusier, II viaggio in Toscana, 1907. Venezia: Marsilio, 1987) 
${ }^{25}$ JEANNERET, Ch. E. Carta a seus pais; Firenze 8, outubro 1907.

${ }^{26}$ JEANNERET, Ch. E. Carta a seus pais; Firenze 8 , outubro 1907.

${ }^{27}$ GRESLERI, G. (1984) op.cit.

Figura 14: Duomo, estudos da fachada. Siena, entre 29 setembro e 05 de outubro 1907. (Fonte: CORBUSIER, Le. Le Corbusier, II viaggio in Toscana, 1907. Venezia: Marsilio, 1987) executado exclusivamente a lápis através de traços rápidos, de maneira bastante despreocupada. O desenho se aproxima muito mais de um croquis, afastando-se cada vez mais do academicismo. Nesse desenho da piazza del Campo Jeanneret não está procurando, como naqueles anteriores, construir um desenho belo e verossímil. A tentativa parece ser a de representar a organização geral do conjunto, apreender a estrutura formal e compositiva da praça, organizada por seus edifícios. Diferente dos outros desenhos onde a tentativa de apreender detalhes específicos da obra determinou uma maior elaboração e consequentemente um tempo muito longo diante do edifício. Nesse estudo, o único objetivo parece ser o de entender essa "estrutura" de organização.

“ Esta manhã estive sobre a cúpula, e desci estupefato de tanta grandeza; retiro todas as bobagens que tinha pensado e talvez escrito sobre o gênio que ousou construir uma coisa assim colossal e assim forte. Subi também até os $94 \mathrm{~m}$ do Palazzo Vechio, subida muito menos interessante porque menos instrutiva do ponto de vista arquitetônico." 25
"Digo adeus a esta magnífica cidade, a esta paisagem tão bonita, te deixo com enorme desprazer, não Ihe encontrarei mais, Ravena e a Lombardia é toda uma outra coisa." 26

A última obra visitada por Jeanneret em Florença é a cúpula de Brunelleschi em Santa Maria del Fiore. No dia 10 de outubro 1907 tem inicio um período mais acelerado da viagem, onde os desenhos são muito poucos, se restringindo às cidades de Lucca e Ravena. Parte de Firenze em 11 de outubro e passa por Lucca e Pistoia, depois Faenza e Ravenna, onde permanece até 17 de outubro. Logo depois vai a Ferrara, Bolonha, Mantova, Peschiera, Gargnano, Riva, Desenzano, Verona, Padova e por fim Veneza onde permanece de 25 de outubro a 7 de novembro, como um grande final, onde as cidades e seus monumentos se sucedem de maneira a imaginar que todo esse percurso "obedecesse a uma regência cuidadosamente traçada." 27

"Veneza brinca conosco, e não nos oferece nada além de chuva. Mas não me importa, tenho o Palácio Ducal e São Marcos e sem dúvida não poderia

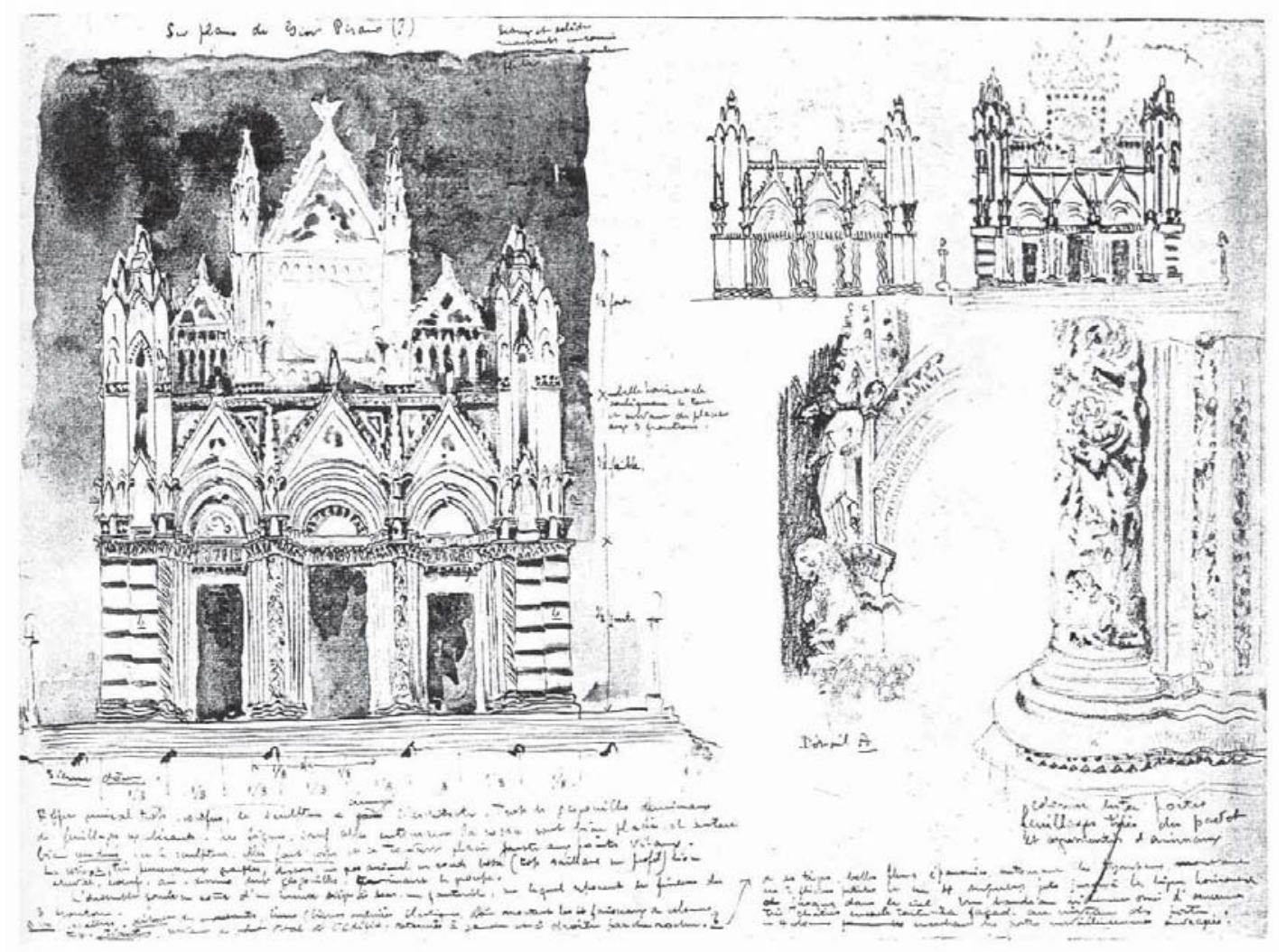




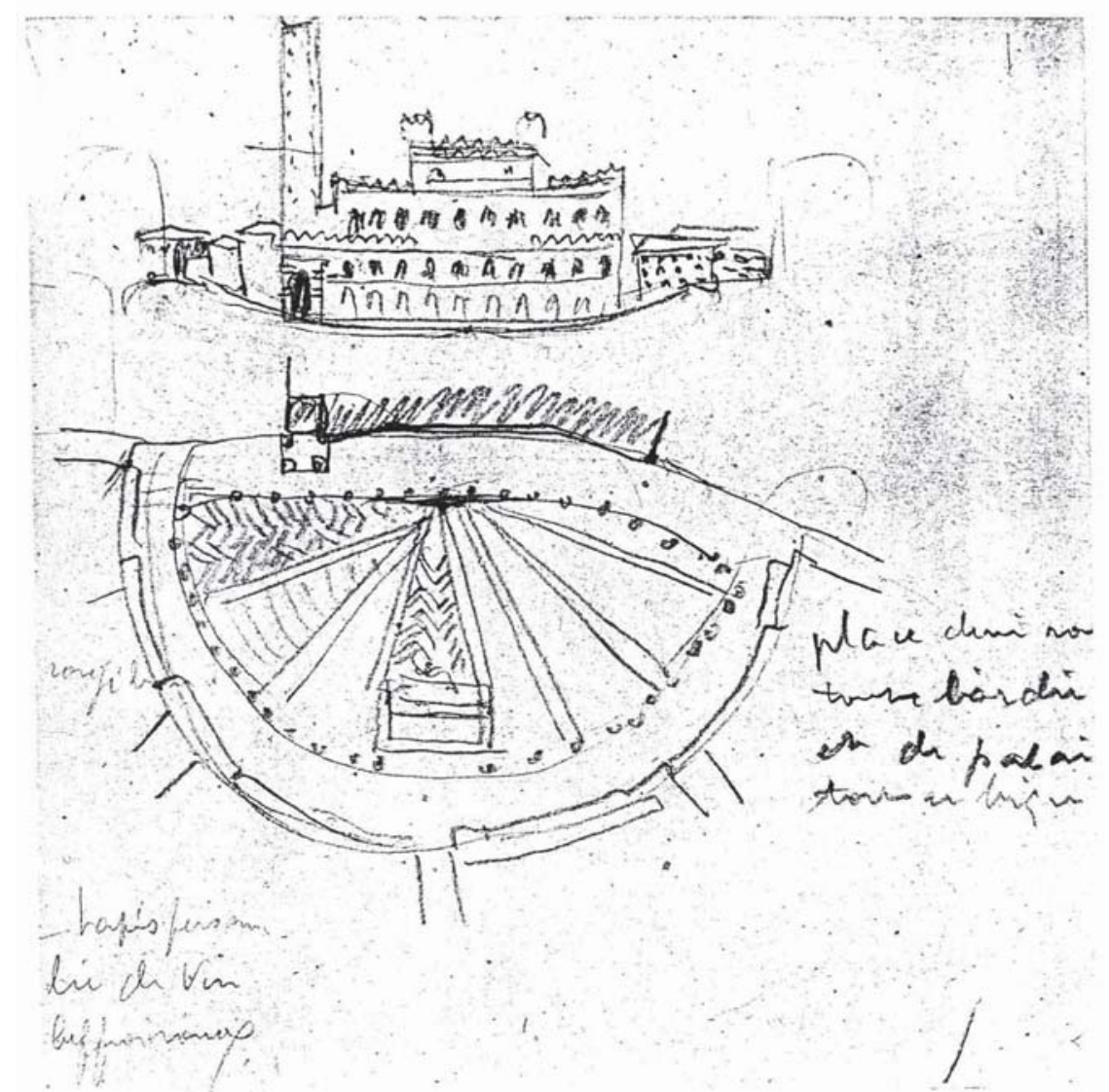

Figura 15: Estudo da Piazza del Campo. Siena (entre 29 setembro e 05 de outubro 1907). Fonte: CORBUSIER, Le. Le Corbusier, II viaggio in Toscana (1907). Venezia: Marsilio, 1987

${ }^{28}$ JEANNERET, Ch. E. Carta a L'Eplattenier; Veneza 25 (?), outubro 1907. imaginar algo mais belo. Depois de ter visitado tantas cidades secundárias, aqui reencontro as emoções de Florença." 28

\section{Os desenhos}

Das setenta e três pranchas (aquarelas e desenhos) realizadas durante essa viagem à Itália, a maior parte delas, cinqüenta pranchas, foi realizada quando hospedado na cidade de Florença. Depois de Florença, é em Siena que Jeanneret realiza outro grande número de desenhos visitando; a piazza del Campo e Torre del Mangia; San Domenico; Palazzo Grottanelli; Duomo e Batistério.

Desse conjunto de desenhos é possível identificar dois grupos; um primeiro grupo onde os desenhos de observação são realizados de forma bastante livre na página, são desenhos especulativos onde comparecem muitos textos explicativos, anotações dos elementos observados e pesquisados, esses em sua maioria observam espaços arquitetônicos, edifícios e seus detalhes; são aqueles realizados sobre a catedral de Pisa, para o palácio Vecchio e de detalhes do Orsanmichelli, estudos do exterior e do interior de santa Croce em Firenze. Um segundo grupo é formado por aqueles desenhos que, podem demandar um tempo maior para a sua elaboração. Desenhos aos quais, além das preocupações com relação ao objeto observado, escolha de um ângulo de enquadramento, e apreensão da riqueza dos detalhes; também se somavam preocupações referentes à composição do desenho na própria página. Desenhos construídos para posteriormente serem cobertos com aquarela, desenhos onde as únicas anotações são quase sempre para nomear o lugar observado e a temática é mais ampla: paisagem, escultura e as pinturas observadas, a arquitetura e muitas vezes seus detalhes. São desenhos como, por exemplo, aqueles sobre o átrio 
${ }^{29}$ JEANNERET, Ch. E. Carta a L'Eplattenier; Firenze, 19 de setembro 1907.

30 JEANNERET, Ch. E. Carta a seus pais; Firenze, 14 de setembro 1907.

${ }^{31}$ JEANNERET, Ch. E. Carta a seus pais; Firenze, 8 de outubro 1907.

${ }^{32}$ JEANNERET, Ch. E. Carta a seus pais; Firenze, 8 de outubro 1907. do Bargello, o capitel de San Vitale em Ravena o detalhe da fachada da catedral de Lucca.

Algumas vezes sobre o mesmo lugar, Jeanneret constrói os dois tipos de desenho, como para o átrio do Bargello, palácio Vecchio e a Catedral de Siena. Cada desenho colhendo aspectos e elementos distintos do edifício. Já nessa primeira viagem à Itália, Jeanneret além dos desenhos em maiores dimensões (formato A3 e subdivisões) elabora também o seu próprio diário de notas, é o que se depreende de sua correspondência de viagem, uma vez que esse diário é tido como desaparecido. Na primeira carta que envia a L'Eplattenier escrita em Firenze, Jeanneret observa: "... escrevo todos os dias, as minhas impressões em meu diário, conforme as circunstâncias me sugerem, será para mim um bom memorial." 29 Ainda na segunda carta que envia aos seus pais (Firenze, 14 de setembro) Jeanneret afirma: "Escrevi, dia após dia minhas impressões em meu caderno de notas; um mistura de coisas, que poderá ser de grande utilidade para mim, nele coloco minhas impressões do momento e relendo corrijo e muitas das vezes recordo melhor." 30

Assim os "carnets" realizados, desde essa primeira viagem, têm um objetivo muito claro para Jeanneret, ele funcionava como um diário pessoal, onde se estabelece uma cumplicidade entre o autor e seu próprio texto, onde o registro do instantâneo é utilizado como uma espécie de interlocutor, com o qual estará constantemente dialogando.

A carta de 8 de outubro, escrita dois dias antes de sua partida de Florença, quando a maior parte dos desenhos desse período da viagem, já havia sido elaborada, revela algumas de suas estratégias e princípios de representação. Revela o momento em que Jeanneret coloca em cheque seu próprio desenho, um desenho treinado até então, a não penetrar na estrutura do objeto, a observá-lo de fora, revelando suas texturas e volumetrias periféricas.

"Tenho os olhos que tremem (tem muito que fazer os meus pobres olhos e o que farei na Itália sem os binóculos da tia Pauline), a cabeça que hoje está pesada, conseqüência de um raio de sol recebido diante da Santa Maria Novella, parado por três horas desenhando das onze às duas." ${ }^{31}$ Um pouco mais adiante, escreve:
"Trabalho muito, mas não consigo fazer o mínimo croqui, que se possa chamar assim. A minha mão é rígida e tensa, sempre cansada, e me agarro ao lápis como a uma âncora de salvação. Paciência, borro tantos papeis, e levarei recordações. Perrin, ele faz desenhos muito bonitos, bem feitos e com arte. Ele se especializa em escultura e um pouco em afrescos, enquanto eu sou obrigado a interessarme de tudo, uma vez que a arquitetura abraça absolutamente tudo, colocando em tudo a sua marca." 32

E ainda:

"Esta manhã desenhei por seis horas empoleirado, mais ou menos em equilíbrio, em uma esquina de oficinas, um desses deliciosos nichos que ornam Orsanmichele."

Jeanneret está experimentando várias técnicas de desenho: lápis sobre papel, ou tinta nanquim e tempera, ou aquarela e a escolha parece estar quase sempre associada aos objetivos do desenho e a natureza do edifício. Utiliza a cor para reproduzir a maior parte dos detalhes e revelar grande parte dos ornamentos e o lápis para desenhos mais analíticos variando assim também o tempo de execução. Mesmo permanecendo várias horas diante de um mesmo edifício, esse desenho rico em detalhes tem um resultado que, como vimos não o agrada. Talvez por que o desenho que representa a arquitetura deva ter características diversas do desenho que observa a escultura ou mesmo a pintura e nesse momento Jeanneret já parece já ter intuído essa diferença. Seus desenhos de espaços internos são muito mais analíticos e desenvolvidos com traços rápidos, enquanto que toda as cores e a riqueza de ornamentos das fachadas dos edifícios parece induzir Jeanneret, a um desenho de grande elaboração e fadiga.

Esse desconforto diante de sua produção, expresso por Jeanneret, parece revelar a compreensão da necessidade do abandono da busca por um desenho virtuoso. Na observação da arquitetura parece compreender que importa, cada vez menos, o desenvolvimento das técnicas tradicionais de desenho e o resultado final "obra". A preocupação com um modelo ideal de desenho, pouco a pouco vai sendo deixada de lado por um desenho que 
${ }^{3}$ JEANNERET, Ch. E. Carta a seus pais; Firenze, 8 de outubro 1907

${ }^{34}$ MASSARETTI; G. Un viaggio trasversale. In: Le Corbusier, Il linguaggio delle pietre. Venezia: Marsilio, 1988.

Figura 16: Palácio Ducal, detalhe da janela. Veneza. Primeiros dias de novembro de 1907. (Fonte: CORBUSIER, Le. Le Corbusier, Il viaggio in Toscana, 1907. Catálogo da mostra org. por Giuliano Gresleri, Venezia: Marsilio, 1987) procura cada vez mais a compreensão espacial daquilo que está sendo observado.

Essas alternativas de desenho estão presentes e embaralhadas nessa viagem à Itália, assim como está presente a sua dúvida com relação à opção pela arquitetura. Mas no decorrer de suas viagens, à Alemanha e ao Oriente 1910-1911, o desenho vai assumindo seu papel, deixa de revelar a superfície da obra, deixa de olhar o edifício como um plano para observá-lo como matéria tridimensional, usando os desenhos e anotações para "penetrar" na obra e colher seus elementos constitutivos e anotar as sugestões que advirem dessa decomposição. Seus desenhos são mais rápidos e questionadores, inquietos. Sua preocupação é sempre menor com relação à sua fatura, estará cada vez mais consciente de que o resultado de seu trabalho não está no papel ou no "caderno de notas", mas no procedimento que com eles desenvolve. Fazendo, do confronto direto com o edifício visitado o pressuposto para a compreensão de um mundo de formas e a ideação de outros significados.

"Três anos atrás quando estava lendo a primeira linha de Grammaire des Arts: " a arquitetura é a primeira das artes" não entendia e não estava mesmo de acordo. Uma viagem a Itália me faz amar o meu trabalho [...]; ter que mudar seria para mim o fim de tudo." 33

A viagem pela Itália é concluída no inverno de 1907, várias outras viagens, como sabemos, com intenções e significados diferentes serão cumpridas por Jeanneret. Porém o desenho permanecerá como lugar do registro, mas agora não da descrição e sim da sugestão que a obra possibilita e o projeto como síntese gráfica de seu confronto tátil com o mundo das formas. Massaretti, caracteriza essa transformação, ocorrida desde sua primeira viagem à Itália, como conseqüência de uma modificação global do 'sentido de conhecimento e da história. "34 O conhecimento (observação e aprendizagem) agora

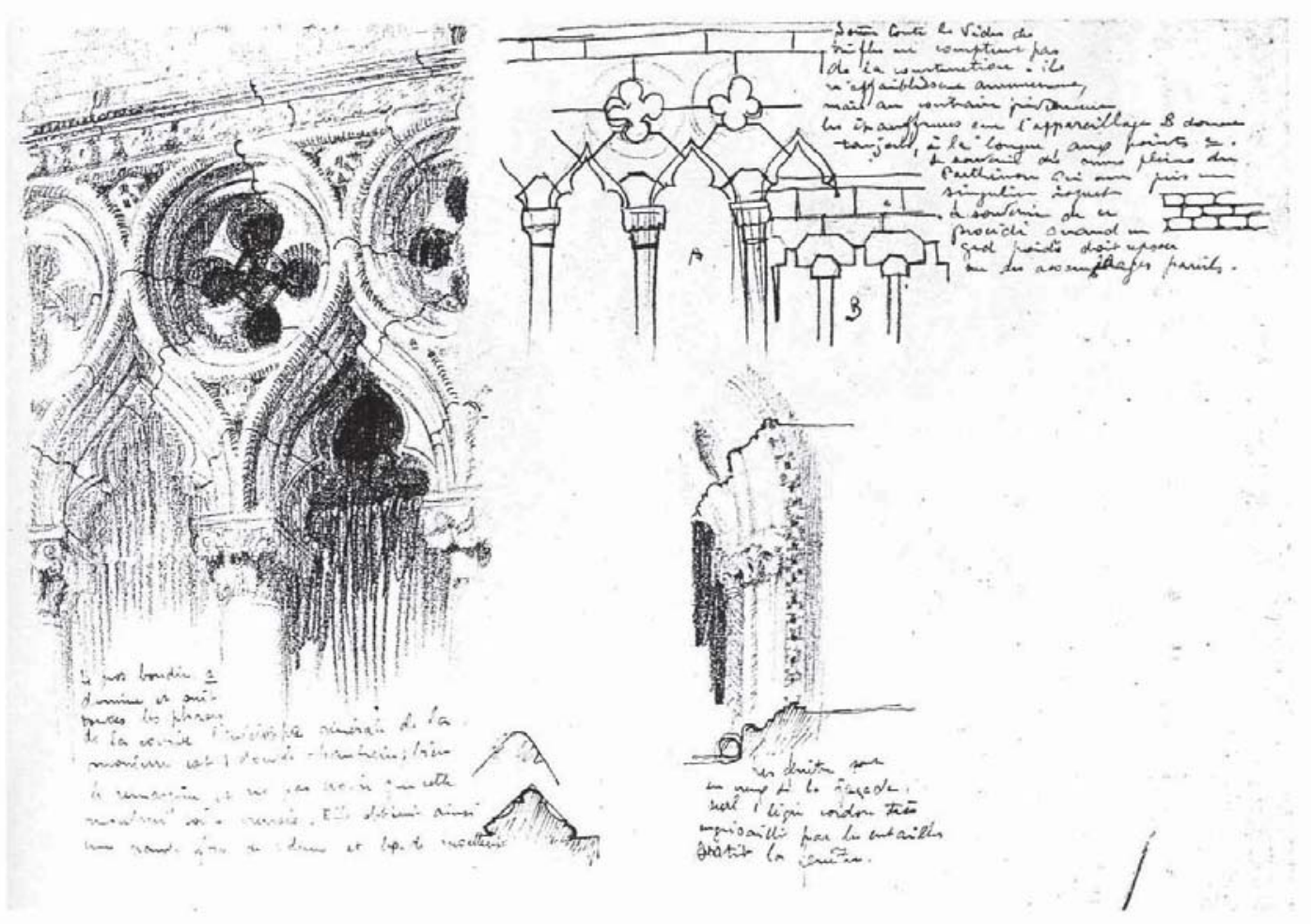


${ }^{35}$ KRUSTRUP, M. "o método que Jeanneret desenvolve em sua viagem ao oriente (isto é, registrar as impressões e os pensamentos em seus pequenos cadernos através de desenhos rápidos) se transforma no instrumento de toda uma vida." Esse é o testemunho, dos setenta e três carnets de desenhos e anotações realizados por Le Corbusier no período de 1914-1964. Tutto è questione di perseveranza, lavoro e di coraggi., In: II linguaggio delle pietre. GRESLERI, G. (org.) Veneza: Marsilio. 1988 p. 51 não é mais só hermenêutica descritiva, afirma ele, mas faz parte de um novo 'saber formativo', "que se faz interpretação crítica da história e do território, da sua geografia, torna-se sede de um projeto 'tomada de posição'." Um particular modo de observação que se transforma no "instrumento de toda uma vida". ${ }^{35}$

\section{Bibliografia}

BRILLI; Attilio (org.) John Ruskin, Viaggi in Itália 18401845. Passigli Editori. Florença 1985

CORBUSIER, Le Le Corbusier, II Linguaggio delle pietre. (catálogo da mostra org. por Giuliano Gresleri), Venezia: Marsilio,1988.
CORBUSIER, Le Le Corbusier, II viaggio in Toscana (1907). (catálogo da mostra org. por Giuliano Gresleri), Venezia: Marsilio, 1987

DE SIMONE, Rosario. Ch. E. Jeanneret - Le Corbusier: Viaggio in Germania 1910-11. Roma: Officina,1989.

GRESLERI, Giuliano (a cura de), catalogo da mostra Viaggio in Oriente: gli inediti di C.E. Jeanneret. fotografo e scritore - (com uma nota de Italo Zannier sobre Le Corbusier fotógrafo). Venezia, Marsilio/Fondation Le Corbusier, 1984.

GRESLERI, G. (org.), 80 Disegni di Le Corbusier. Bolonha: Ed.ente fiere di Bolonha, 1977.

LUCAN, J. (org.), Le Corbusier, una enciclopedia. Volume pubblicado in occasione della mostra "L'avventura Le Corbusier". Milano: Electa, 1988. 
O olho e a mão, o desenho na primeira viagem de Le Corbusier

Joubert José Lancha

\section{Abstract}

Since the Renaiscence, drawing has been a main issue for the architects, so fundamental as study of the past. Their studies developed in a paralel way, promoting and stimulating each other. The work of architecture has a specific integrity and an absolute closure: drawings help to decompose this integrity and to break its hermetism. The countless drawings made by Le Corbusier in travels during his study years are privileged exemples of this relationship: the buildings and its analitical drawings turned out to be stimulus for the architectural project. 